\title{
Birth Order and Voter Turnout
}

\author{
Bernt Bratsberg ${ }^{1}$ (D), Christopher T. Dawes ${ }^{2}$, Andreas Kotsadam ${ }^{1}$, Karl-Oskar Lindgren ${ }^{3}$ (D), \\ Richard Öhrvall $^{4}$ (D), Sven Oskarsson ${ }^{3 *}$ (D) and Oddbjørn Raaum ${ }^{1}$ \\ ${ }^{1}$ The Ragnar Frisch Centre for Economic Research, Oslo, Norway, ${ }^{2}$ Wilf Family Department of Politics, New York University, \\ New York, United States, ${ }^{3}$ Department of Government, Uppsala University, Uppsala, Sweden and ${ }^{4}$ Centre for Local \\ Government Studies (CKS), Linköping University, Linköping, Sweden and Research Institute of Industrial Economics (IFN), \\ Stockholm, Sweden \\ *Corresponding author. E-mail: sven.oskarsson@statsvet.uu.se
}

(Received 15 January 2019; revised 14 October 2019; accepted 12 December 2019; first published online 10 July 2020)

\begin{abstract}
Previous studies have stressed the role of a child's family environment for future political participation. This field of research has, however, overlooked that children within the same family have different experiences depending on their birth order. First-borns spend their first years of life without having to compete over their parents' attention and resources, while their younger siblings are born into potential rivalry. We examine differences in turnout depending on birth order, using unique population-wide individual level register data from Sweden and Norway that enables precise within-family estimates. We consistently find that higher birth order entails lower turnout, and that the turnout differential with respect to birth order is stronger when turnout is lower. The link between birth order and turnout holds when we use data from four other, non-Nordic countries. This birth order effect appears to be partly mediated by socio-economic position and attitudinal predispositions.
\end{abstract}

Keywords: voter turnout; birth order; political socialization; family size

Understanding why citizens choose to vote in elections is one of the most studied questions in political science. While a myriad of individual- and institutional-level factors are known to be related to voting throughout one's life, scholars of political behavior have pinpointed adolescence and early adulthood as a formative period of political development (Dinas 2013; Schuman and Scott 1989). In particular, a child's family environment has been shown to influence their longterm political engagement (Cesarini, Johannesson and Oskarsson 2014; Gidengil, Wass and Valaste 2016; Gimpel, Lay and Schuknecht 2003; Pacheco 2008; Plutzer 2002; Verba, Schlozman and Burns 2005).

Family is an important source of political socialization; children learn about politics from, and observe the political behavior of, their parents. Exposure to political discussion in the home has been consistently demonstrated to be one of the strongest predictors of whether or not a child will vote as an adult (Gimpel, Lay and Schuknecht 2003; Pacheco 2008; Verba, Schlozman and Burns 2005). In addition to teaching children about politics, parents also provide non-political resources that help to foster a child's later political engagement. While scholars of political behavior have firmly established the importance of the family in shaping adult political participation, this research has not taken into account that growing up in a specific family can be a different experience for children of different birth orders. In this article, we test whether the order in which a child is born into a family influences their likelihood of voting as an adult. There are at least three prevailing theories linking birth order to adult outcomes.

\footnotetext{
(C) The Author(s) 2020. This is an Open Access article, distributed under the terms of the Creative Commons Attribution licence (http://crea tivecommons.org/licenses/by/4.0/), which permits unrestricted re-use, distribution, and reproduction in any medium, provided the original work is properly cited.
} 
The first two focus on how birth order affects the cognitive development process. The confluence theory, based on the work of Zajonc and Markus (1975), maintains that earlier-born siblings are advantaged because the average family intellectual environment declines with each successive birth as children are less intellectually developed than adults. That is, whereas first-borns exclusively receive intellectual stimulation from their parents during their initial years of life, laterborns must also interact with their older siblings, which hampers their development relative to first-borns. The resource dilution theory formulated by Blake (1981) makes a similar prediction about the relationship between birth order and cognitive development, but stresses the access to household resources. As the size of the family grows, the share of parental attention and resources each later child receives is smaller since it must be distributed among all children. ${ }^{1}$ In support of this resource mechanism, Black, Grönqvist and Öckert (2018) found that parents spent less time discussing school work with later-born children.

A third theory, posited by Sulloway (1996), focuses instead on interactions between siblings and argues that children sort themselves into distinct 'family niches' in order to successfully compete with one another for parental resources. First-borns develop traits, such as conscientiousness, that allow them to preserve their dominant status in the sibling hierarchy, whereas younger siblings try to differentiate themselves from their siblings by being unconventional and more sociable. Black, Grönqvist and Öckert (2018) provide empirical evidence that birth order is correlated with different personality traits and that first-born children are more likely to choose occupations requiring leadership ability and conscientiousness.

To the extent that birth order is related to cognitive development and personality, it could also be expected to affect political participation. There is strong and compelling evidence that both cognitive ability (Dawes et al. 2014) and various personality traits such as the Big Five factors (Gerber et al. 2011; Mondak et al. 2010) constitute important determinants of political activity. Yet while a handful of descriptive studies have investigated whether first-borns are overly represented among elected officials (Andeweg and Berg 2003; Forbes 1971; Hudson 1990; Newman and Taylor 1994; Somit, Arwine and Peterson 1994; Zweigenhaft 1975), the importance of birth order has been of greater interest to economists, sociologists and psychologists than to political scientists. The dearth of research on political outcomes is likely due to the type of data necessary to cleanly separate the influence of birth order from confounding factors like family size and birth cohort. Recent work on birth order in other domains has utilized large population registries containing data on family structure, allowing researchers to examine within-family differences in adult outcomes to convincingly identify the effect of birth order (for example Black, Devereux and Salvanes 2005).

We use population-wide data from Sweden and Norway to study the importance of birth order for voter turnout. Our within-family estimates show that the probability of voting is monotonically and strongly decreasing in birth order. The results also suggest that the birth-order differential is greater the lower the average turnout rate. We show that these results are externally valid by investigating the link between birth order and turnout in a number of samples from four other, non-Nordic countries. Finally, we shed light on possible mechanisms by showing that birth order relates to attitudinal factors known to predict voter turnout. We also show that socio-economic status accounts for part of the birth order influence on political participation.

\section{Institutional Setting and Data}

To study the relationship between birth order and voter turnout, we use administrative data on validated turnout from four recent elections in Norway and Sweden. In Norway, we study the national parliamentary election in 2013 and the local-level elections in 2015, and in Sweden,

\footnotetext{
${ }^{1}$ Although parental economic resources are likely to increase over time, this increase is unlikely to be large enough to fully compensate for the effect of additional children.
} 
the European Parliamentary election in 2009 as well as the election to the national parliament in 2010.

In Norway, the turnout data have been obtained from electronic voter records for all municipalities that had computerized their systems. The number of Norwegian municipalities using electronic records is increasing over time. Consequently, our data cover 28 per cent of all eligible voters in 2013 and 43 per cent in the 2015 election. $^{2}$

Since electronic voting records are not used in Sweden, the turnout data have instead been gathered by scanning and digitizing the complete election rolls for the 2009 and 2010 elections. For these two elections, we have access to validated individual-level turnout information for 95 per cent of the electorate and the reliability of the digitized data has been shown to be very high (Lindgren, Oskarsson and Persson 2019).

For both the Swedish and Norwegian samples, the turnout data are merged with various administrative registers using unique personal identifiers. The linked datasets contain detailed information on family relations, including birth order, as well as various demographic and socio-economic characteristics (see the Appendix for a more detailed description of the data and the institutional context).

We have invoked a number of sample restrictions in order to ensure consistency across countries, elections and model specifications. Most importantly, we restrict our analyses to individuals who have at least one and at most four siblings. ${ }^{3}$ Moreover, the samples are restricted to families in which all siblings are aged 20-65 at the time of the elections. To reduce measurement error in the birth-order variable, we further restrict the samples to native-born children of two nativeborn parents and exclude individuals who have grown up in families with twins. With these restrictions, the sizes of the samples used for the empirical analyses range from about 300,000 (Norway 2013) to 2,580,000 individuals (Sweden 2010).

\section{Empirical Estimation}

Figure 1 shows that voter turnout is markedly lower among individuals of higher birth order in each of the four elections studied. The strength of the relationship appears to be inversely related to the overall turnout rate. For the election with the highest turnout (Sweden 2010), first-born siblings have a 6-percentage-point higher vote propensity than that of fifth-born siblings, whereas the corresponding figure for the election with the lowest turnout (Sweden 2009) is almost twice as large (11.5 percentage points).

It would, however, be a mistake to interpret these raw correlations causally because the relationship between birth order and turnout is likely to be confounded by a number of factors that vary across and within families. One such factor is family size, since it is only larger families that have children of higher birth order (Black, Devereux and Salvanes 2005). Moreover, children of higher birth order belong to more recent cohorts than their older siblings and therefore the relationship between birth order and turnout may also be confounded by age or secular trends in turnout. Similarly, higher-order children have older parents, which may also bias the birth-order estimates if not adjusted for (Black, Grönqvist and Öckert 2018).

To handle these challenges, we rely on a within-family regression model of the following type:

$$
y_{i j}=\alpha+\sum_{k=2}^{m} \beta_{k} I\left(B O_{i j}=k\right)+\Gamma^{\prime} X_{i j}+\mu_{j}+\varepsilon_{i j}
$$

where $y_{i j}$ denotes the outcome of interest (voting) for individual $i$ in family $j, B O_{i j}$ records the birth order of the individual, $\mu_{j}$ represents family-level (mother) fixed effects, and $\varepsilon_{i j}$ is an individual-level error term. The fixed effects account for the importance of all family

\footnotetext{
${ }^{2}$ The levels of turnout in the Norwegian samples are representative of the turnout levels in the full population.

${ }^{3}$ In both Norway and Sweden, less than 3 per cent of all individuals come from families with more than five children.
} 


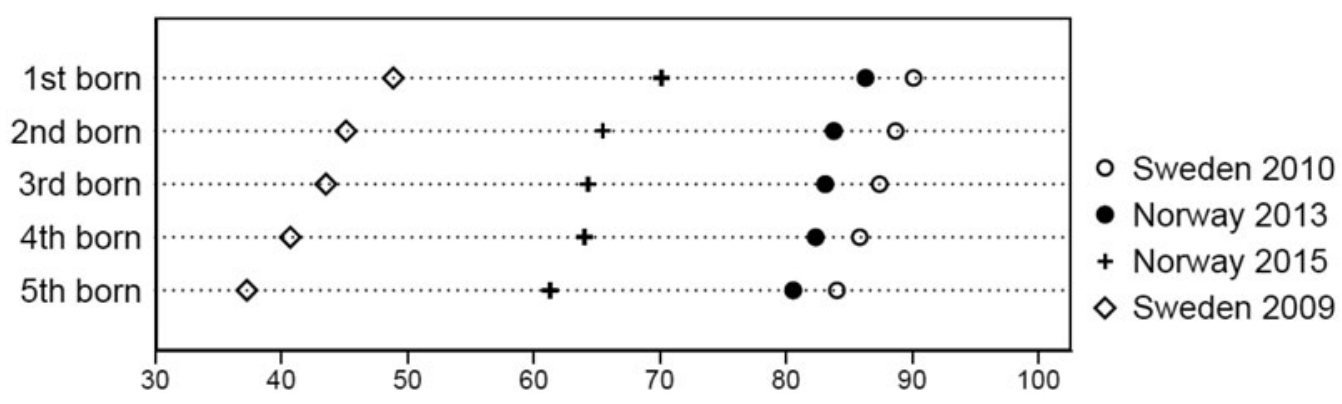

Figure 1. Turnout by birth order

Table 1. Birth order and turnout, baseline results

\begin{tabular}{|c|c|c|c|c|}
\hline & \multicolumn{2}{|c|}{ Norway } & \multicolumn{2}{|c|}{ Sweden } \\
\hline & National election 2013 & Local election 2015 & EP election 2009 & National election 2010 \\
\hline Second child & $\begin{array}{c}-0.018^{\star \star \star} \\
(0.002)\end{array}$ & $\begin{array}{c}-0.034^{\star \star \star} \\
(0.002)\end{array}$ & $\begin{array}{c}-0.044^{\star \star \star} \\
(0.001)\end{array}$ & $\begin{array}{c}-0.012^{\star \star \star} \\
(0.001)\end{array}$ \\
\hline Third child & $\begin{array}{c}-0.025^{\star \star \star} \\
(0.004)\end{array}$ & $\begin{array}{c}-0.051^{\star \star \star} \\
(0.004)\end{array}$ & $\begin{array}{c}-0.064^{\star \star \star} \\
(0.002)\end{array}$ & $\begin{array}{c}-0.018^{\star \star \star} \\
(0.001)\end{array}$ \\
\hline Fourth child & $\begin{array}{c}-0.033^{\star * *} \\
(0.006)\end{array}$ & $\begin{array}{c}-0.066^{\star * \star} \\
(0.006)\end{array}$ & $\begin{array}{c}-0.083^{* * *} \\
(0.003)\end{array}$ & $\begin{array}{c}-0.024^{\star \star \star} \\
(0.002)\end{array}$ \\
\hline Fifth child & $\begin{array}{c}-0.051^{\star \star *} \\
(0.010)\end{array}$ & $\begin{array}{c}-0.099^{* * *} \\
(0.009)\end{array}$ & $\begin{array}{c}-0.103^{* \star *} \\
(0.004)\end{array}$ & $\begin{array}{c}-0.033^{\star * *} \\
(0.003)\end{array}$ \\
\hline Turnout & 0.84 & 0.67 & 0.46 & 0.89 \\
\hline Observations & 305,031 & 532,429 & $2,488,725$ & $2,580,650$ \\
\hline
\end{tabular}

Note: all models include controls for gender, birth year and family (mother) fixed effects. Standard errors, shown in parentheses, allow for clustering at the family level. ${ }^{\star \star \star} /{ }^{\star \star} /{ }^{\star}$, indicates significance at the $1 / 5 / 10$ per cent levels.

characteristics shared by siblings - including, but not restricted to, sibship size, parental age and socio-economic status - and thereby assure that there are no confounding across-family processes at work. Even with the within-family design it will, however, be necessary to control for potential confounders that vary between siblings. For this reason, we also include the vector $\Gamma^{\prime} \mathrm{X}_{i j}$ in the equation with controls for birth cohort and gender.

\section{Results}

We present the results from the within-family regression models in Table 1 . Since we will compare coefficients across models, samples and groups, we employ linear probability models instead of nonlinear models (Mood 2010). However, as the results in Appendix Table A3 show, the overall pattern of effects is similar if we use a conditional logit model instead.

There is clear evidence of a monotonically increasing negative effect of birth order on voter turnout in all four elections. The estimates also support the view that the magnitude of this relationship grows stronger as overall turnout declines. In the two national elections, where voter turnout is above 80 per cent, the differences in vote propensity between first- and second-borns are 1.8 percentage points (Norway) and 1.2 percentage points (Sweden) and between first- and fifth-borns 5.1 and 3.3 percentage points (see Columns 1 and 4 of Table 1). For the Swedish election for the European Parliament in 2009, where overall turnout was below 50 per cent, the corresponding differences are as high as 4.4 and 10.3 percentage points, respectively (Column 3 ). The turnout differential with respect to birth order for the Norwegian local election, where turnout was about 66 per cent, falls in between the lowest and second-highest turnout election estimates (Column 2). 


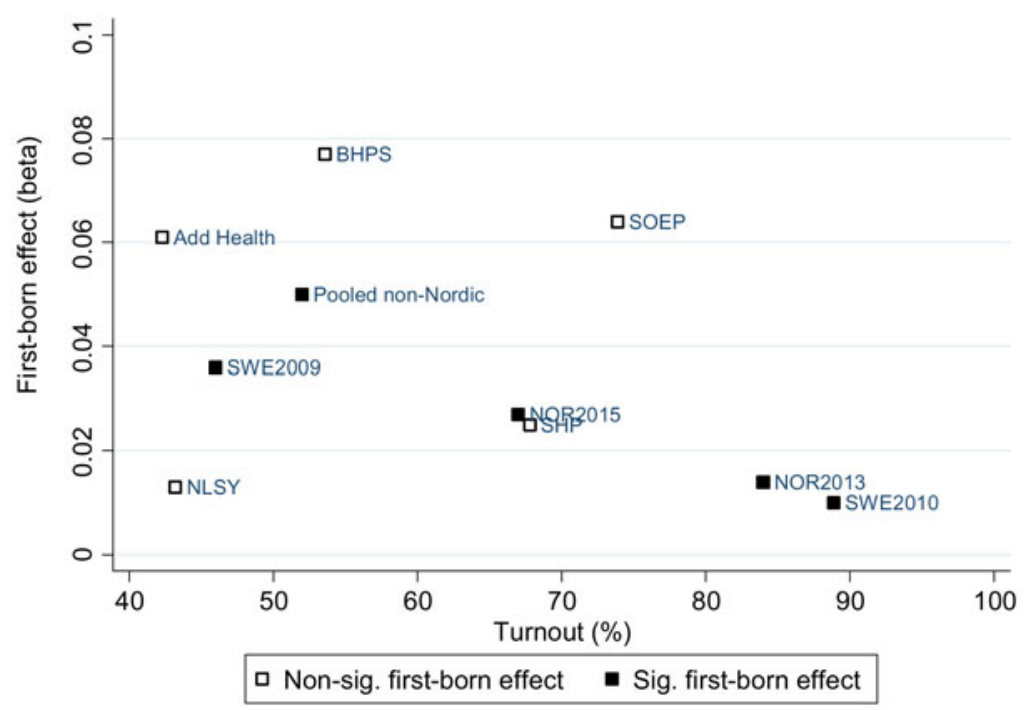

Figure 2. First-born turnout premium in nine samples (within-family estimates)

The magnitude of these turnout differentials is large. For instance, the expected difference in turnout between a first- and fifth-born sibling in the Swedish European Parliament election was almost one-fourth of the average turnout in that election. To further put the magnitude of these associations into perspective, Appendix Table A1 reports within-family estimates of one of the strongest predictors of voter turnout highlighted in the literature: having completed a college degree. The differences in turnout rates between first- and fifth-borns amount to about two-thirds of the corresponding college differences.

Our main findings are robust to changes in model specification and sample restrictions. In particular, we show in the Appendix that the results are similar for men and women (Table A2) as well as when not including any restrictions on the individual's age (Table A4). As later-born children are more likely to grow up with divorced parents, we find it reassuring that the results are similar when we restrict the samples to individuals from stable families (Table A5). While somewhat less precise in the sample with the fewest observations, we also find that the pattern of estimates seems to be similar in families of different sizes (Tables A6 and A7).

Finally, we test for heterogeneity across age differences between siblings (Table A8) and parental education (Table A9). We find some, although not very strong, evidence that the association between birth order and voter turnout is somewhat more pronounced among siblings who are close in age (at least in Sweden) and in less-educated families. These differences are rather small and imprecisely estimated and should therefore not be overstated.

Our analysis reveals that birth order has a strong and robust effect on voter turnout in both Norway and Sweden, and that the magnitude of these voting differentials seems to be inversely related to overall turnout. Two natural follow-up questions concern external validity and possible mechanisms underlying the link between birth order and voter turnout. In Appendix Table A10, we present results from five samples across four countries (Germany, Switzerland, the UK and the US) that all include information on birth order and voter turnout. Table A10 also displays estimates based on pooling the five survey samples. Although the estimates from each of the non-Nordic samples are all insignificant, the first-borns in the pooled sample are significantly more likely to vote than their siblings. The overall pattern of the estimates in these smaller samples corroborates the findings in the two Nordic countries. 

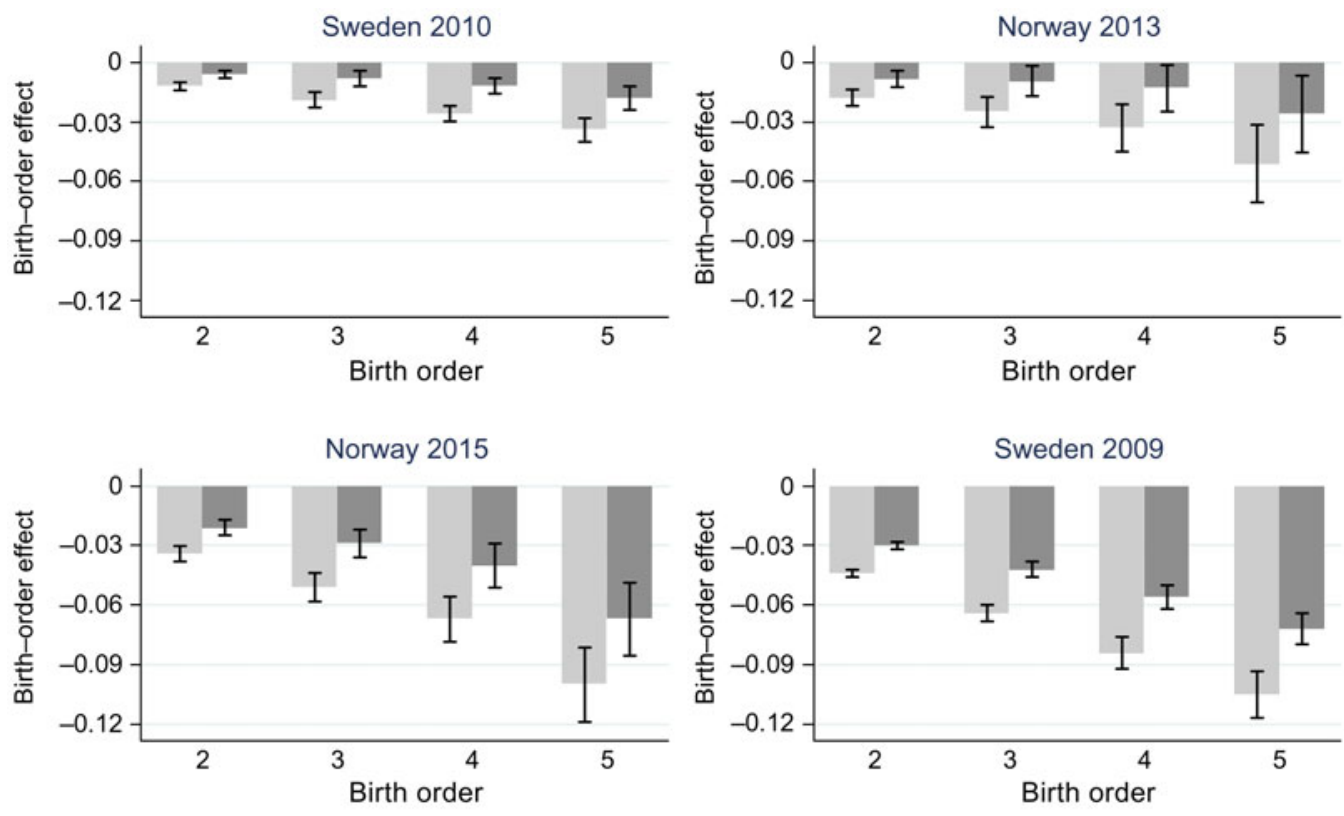

Baseline

Conditional on earnings and education

Figure 3. Conditional birth-order effects

The main results from these analyses are summarized in Figure 2. The figure displays point estimates from within-family models, regressing turnout on a dummy indicating first-born status (as opposed to later-borns) from all samples. ${ }^{4}$ Solid squares denote significance at the 5 per cent level. Two patterns stand out in the figure. First, in all samples the first-born turnout premium is positive. Secondly, the magnitude of the turnout difference between first- and later-borns decreases as the overall turnout rate increases.

Turning next to potential mechanisms, in Figure 3 we examine the extent to which the socioeconomic position accounts for the observed relationship between birth order and turnout. The light grey bars in the figure show the unmediated turnout effects reported above, and the dark grey bars indicate the corresponding estimates when controlling for (percentile ranked) education and earnings. Admittedly, mediation analyses are complicated, and we do not control for all the variables that are correlated with the mediators and turnout. Thus the conditional coefficients should not be given a causal interpretation (for example, Imai et al. 2011). Nevertheless, the regression results indicate that there are birth-order mechanisms affecting voter turnout that are orthogonal to those influencing earnings and education as there are still sizable turnout differentials with respect to birth order. To judge from these results, better education and earnings outcomes of earlier-born siblings can, at most, account for between one-third and one-half of the overall turnout effect. As can be seen from the error bars, which represent 95 per cent confidence intervals, the reduction in the birth-order coefficients when controlling for socio-economic status is usually statistically significant. The confidence intervals do not overlap except for some of the higher-order effects in the Norwegian sample, which contains fewer observations.

\footnotetext{
${ }^{4}$ Our main reason for using a dummy variable to differentiate first-borns from those born later in these analyses is the loss of precision due to the much smaller sample sizes in the five survey studies. However, in the Appendix we show that estimates from models in which the full birth-order specification is used are reasonably similar to the much more precise pattern of results obtained when using the Norwegian and Swedish data.
} 
Another possibility is that part of the influence of birth order is mediated by different attitudinal factors shown to predict voter turnout in earlier studies. Appendix Table A10 provides some evidence along these lines based on the five smaller samples. Once again, the estimates are somewhat imprecise but they consistently show that being first-born is positively related to interest in politics (Verba, Schlozman and Brady 1995), internal as well as external political efficacy (Finkel 1985), and support for the norm of voting as a civic duty (Blais and Young 1999).

\section{Concluding Remarks}

We test whether the exogenously determined order in which children are born into a family is related to whether they vote as adults. To convincingly identify the effect of birth order, we utilize population registers from two similar Scandinavian countries, Sweden and Norway, that allow us to provide precise estimates from within-family models.

Across four separate elections, we consistently observe a negative relationship between birth order and voting. Moreover, the fact that the (absolute) size of the coefficients are monotonically increasing in birth order shows that there is more to this relationship than a simple difference between first-borns and younger siblings. Interestingly, in line with Tingsten's (1937) 'law of dispersion', the birth-order differentials in turnout are larger in low-turnout, second-order elections. Since these elections are generally considered by voters, parties and the media to be less important than first-order elections (Reif and Schmitt 1980), they tend to take place in a more information-poor environment, thus making it more challenging for voters to participate. As is the case with education (Lefevere and Van Aelst 2014), factors related to birth order appear to enable individuals to overcome the challenges of second-order elections.

Our investigation of birth order and voting is based on theories that point to the differential access to resources resulting from when a child is born into a family. While we provide evidence that the relationship between birth order and turnout is partly mediated by socio-economic position as well as attitudinal predispositions, future research should more comprehensively explore other possible mechanisms.

Substantively, the relationship we find between birth order and voting is important for three main reasons. First, our findings suggest a more nuanced picture of how parents influence the political participation of their children. We show that siblings with the same parents develop different voting behaviors. Later-born children, even in a high socio-economic-status home, are less likely to vote than their older siblings. Therefore, measures such as parental socio-economic status provide an incomplete picture of access to resources that are important for political development. Secondly, our study demonstrates how non-political factors outside of one's control, like when they were born (Meredith 2009), are important predictors of an individual's likelihood of voting. Finally, participation differences are particularly important if siblings have different policy preferences. Sulloway (1996) argued that first-borns are more politically conservative than later-borns, but Freese, Powell and Steelman (1999) failed to find any evidence of this based on the General Social Survey. However, since birth order has been shown to influence outcomes such as health (Black, Devereux and Salvanes 2016), and educational (Barclay, Hällsten and Myrskylä 2017) and occupational status (Black, Grönqvist and Öckert 2018), siblings may have different preferences for specific policies. One important avenue for future research is thus to investigate whether or not this is the case. Another is to examine whether the pattern found here also generalizes to other forms of political participation. In particular, it would be interesting to use the methodology employed here to examine whether younger siblings are in fact more likely, as the familyniche theory suggests, to partake in more non-conventional forms of political participation such as boycotting or public protesting. Although the between-family study of Førland, Korsvik and Christophersen (2012) did not find this to be the case, it remains an open question whether these results hold if we compare siblings growing up in the same families. 
Supplementary material. Data replication sets are available in Harvard Dataverse at: https://doi.org/10.7910/DVN/ AN1SDD and online appendices at: https://doi.org/10.1017/S0007123419000826.

Acknowledgements. We are grateful for helpful comments from participants at the APSA conference in San Francisco in 2017 and the Oslo Turnout Workshop in 2017. This research was financially supported by the Swedish Research Council (VR) and the European Research Council (ERC). The paper is also part of the projects Who Votes and Why and European Strains at ESOP, University of Oslo and the Frisch Centre. Data from Statistics Norway have been essential. European Strains is funded by the Research Council of Norway through its Europe in Transition funding scheme, project number 227072/F10.

\section{References}

Andeweg R and Berg SVD (2003) Linking birth order to political leadership. Political Psychology 24(3), 605-623.

Barclay K, Hällsten M and Myrskylä M (2017) Birth order and college major in Sweden. Social Forces 96(2), 629-660.

Black SE, Devereux PJ and Salvanes KG (2005) The more the merrier? The Quarterly Journal of Economics 120(2), 669-700.

Black SE, Devereux PJ and Salvanes KG (2016) Healthy (?), wealthy, and wise. Economics \& Human Biology 23, 27-45.

Black SE, Grönqvist E and Öckert B (2018) Born to lead? Review of Economics and Statistics 100(2), 274-286.

Blais A and Young R (1999) Why do people vote? Public Choice 99(1-2), 39-55.

Blake J (1981) Family size and the quality of children. Demography 18(4), 421-442.

Bratsberg B et al. (2020) Replication Data for "Birth Order and Voter Turnout", https://doi.org/10.7910/DVN/AN1SDD, Harvard Dataverse, V1.

Cesarini D, Johannesson M and Oskarsson S (2014) Pre-birth factors, post-birth factors, and voting. American Political Science Review 108(01), 71-87.

Dawes C et al. (2014) The relationship between genes, psychological traits, and political participation. American Journal of Political Science 58(4), 888-903.

Dinas E (2013) Opening 'openness to change' political events and the increased sensitivity of young adults. Political Research Quarterly 66(4), 868-882.

Finkel SE (1985) Reciprocal effects of participation and political efficacy. American Journal of Political Science 29(4), 891-913.

Forbes GB (1971) Birth order and political success. Psychological Reports 29(3_suppl), 1239-1242.

Førland TE, Korsvik TR and Christophersen K-A (2012) Brought up to rebel in the sixties. Political Psychology 33(6), 825-838.

Freese J, Powell B and Steelman LC (1999) Rebel without a cause or effect. American Sociological Review 64(2), 207-231.

Gerber AS et al. (2011) Personality traits and participation in political processes. The Journal of Politics 73(3), 692-706.

Gidengil E, Wass H and Valaste M (2016) Political socialization and voting. Political Research Quarterly 69(2), 373-383.

Gimpel JG, Lay JC and Schuknecht JE (2003) Cultivating Democracy: Civic Environments and Political Socialization in America. Washington, DC: Brookings Institution Press.

Hudson VM (1990) Birth order of world leaders. Political Psychology 11(3), 583-601.

Imai K et al. (2011) Unpacking the black box of causality. American Political Science Review 105(4), 765-789.

Lefevere J and Van Aelst P (2014) First-order, second-order or third-rate? Electoral Studies 35, 159-170.

Lindgren K-O, Oskarsson S and Persson M (2019) Enhancing electoral equality. American Political Science Review 113(1), $108-122$.

Meredith M (2009) Persistence in political participation. Quarterly Journal of Political Science 4(3), 187-209.

Mondak JJ et al. (2010) Personality and civic engagement. The American Political Science Review 104(1), 85-110.

Mood C (2010) Logistic regression. European Sociological Review 26(1), 67-82.

Newman J and Taylor A (1994) Family training for political leadership. Political Psychology 15(3), 435-442.

Pacheco JS (2008) Political socialization in context. Political Behavior 30(4), 415-436.

Plutzer E (2002) Becoming a habitual voter. The American Political Science Review 96(1), 41-56.

Reif K and Schmitt H (1980) Nine second-order national elections. European Journal of Political Research 8(1), 3-44.

Schuman H and Scott J (1989) Generations and collective memories. American Sociological Review 54(3), 359-381.

Somit A, Arwine A and Peterson SA (1994) Birth order and British prime ministers. Political Studies 42(1), 120-127.

Sulloway FJ (1996) Born to Rebel. New York: Pantheon Books.

Tingsten H (1937) Political Behavior. London: P. S. King \& Son.

Verba S, Schlozman K and Burns N (2005) Family ties. In Zuckerman A (ed.), The Social Logic of Politics. Philadelphia, PA: Temple University Press, pp. 95-115.

Verba S, Schlozman KL and Brady HE (1995) Voice and Equality. Cambridge, MA: Harvard University Press.

Zajonc RB and Markus GB (1975) Birth order and intellectual development. Psychological Review 82(1), 74.

Zweigenhaft RL (1975) Birth order, approval-seeking and membership in congress. Journal of Individual Psychology 31(2), 205-210.

Cite this article: Bratsberg B, Dawes CT, Kotsadam A, Lindgren K-O, Öhrvall R, Oskarsson S, Raaum O (2022). Birth Order and Voter Turnout. British Journal of Political Science 52, 475-482. https://doi.org/10.1017/S0007123419000826 